\title{
RANCANG BANGUN SISTEM ADMINISTRASI PERIZINAN KURSUS UNTUK MENINGKATKAN PELAYANAN MASYARAKAT PADA PUSAT PEMERINTAHAN
}

\author{
Novi Cholisoh ${ }^{1}$, Henderi $^{2}$, Siti Khodijah ${ }^{* 3}$ \\ ${ }^{1}$ Program Studi Manajemen Informatika Universitas Raharja ${ }^{2,3}$ Program Studi Komputerisasi \\ Akuntansi Universitas Raharja \\ email : 'novi@ raharja.info, ${ }^{2}$ henderi@ raharja.info, ${ }^{* 3}$ siti.khodijah@ raharja.info
}

\begin{abstract}
Abstraksi
Dinas Penanaman Modal Pelayanan Terpadu Satu Pintu (DPMPTSP) merupakan salah satu bagian di Pusat Pemerintahan Kabupaten / Kota yang melayani perizinan, salah satunya kursus. Dalam prakteknya, beberapa kabupaten / kota sebenarnya memliki sistem perizinan online, selain itu DPMPTSP juga memiliki website tersendiri untuk perizinan kursus namun pada prakteknya kedua aplikasi sistem ini jarang dipakai oleh masyarakat yang ingin mengurus izin karena berbagai alasan, diantaranya kendala persyaratn administratif yang dirasa menyulitkan, kendala akses yang terkadang bermasalah, lamanya waktu respon disbanding datang langsung dan lain sebagainya. Tujuan dari penelitian ini untuk mengetahui proses perizinan kursus, menciptakan konsep sistem perizinan kursus yang efektif dan efisien, dan menciptakan konsep sistem perizinan kursus yang cepat dan akurat. Maka penulis mendapatkan altermatif pemecahan masalah bahwa masyarakat harus terbiasa dengan sistem online dan prosedur dalam perizininan kursus seharusnya tidak terlalu panjang agar masyarakat lebih mudah dalam mengurus perizinan, selain itu juga dengan adanya usulan sistem ini, diharapkan mampu menjadi pendamping untuk sistem perizinan yang sudah ada dalam menangani yang dating langsung.
\end{abstract}

Kata kunci: Perizinan, Kursus, Pelayanan masyarakat

\begin{abstract}
The One Stop Integrated Services Investment Office (DPMPTSP) is one part of the Regency / City Government Center that serves licensing, one of which is the course. In practice, some regencies / cities actually have an online licensing system, besides that DPMPTSP also has its own website for course licensing but in practice both application systems are rarely used by people who want to take care of permits for various reasons, including administrative requirements that are difficult, access constraints that are sometimes problematic, the length of response time is compared to direct dating and so on. The purpose of this study is to find out the process of licensing the course, create an effective and efficient licensing system concept, and create a concept of a fast and accurate licensing system course. So the authors get alternative solutions to the problem that the public must be familiar with the online system and procedures in licensing the course should not be too long so that the community is easier to manage permits, besides the proposed system, is expected to be a companion to the existing licensing system dealing with dating directly.
\end{abstract}

Keywords: Licensing, Course, Community Service 


\section{PENDAHULUAN}

Dinas Penanaman Modal Pelayanan Terpadu Satu Pintu (DPMPTSP) merupakan salah satu bagian di Pusat Pemerintahan Kota Tangerang yang melayani perizinan salah satunya kursus. Dalam prakteknya DPMPTSP ini sebenarnya sudah memliki sistem perizinan online melalui tangerang live pada aplikasi smartphone, selain itu DPMPTSP juga memiliki website tersendiri untuk perizinan kursus namun pada prakteknya kedua aplikasi sistem ini jarang dipakai oleh masyarakat yang ingin mengurus izin karena berbagai alasan. Hal ini bisa dilihat dari banyaknya masyarakat yang datang langsung ke DPMPTSP untuk mengurus perizinan tanpa menggunakan sistem yang digunakan sebelumnya.

Suatu sistem yang terotomatisasi dapat membantu petugas dalam menyelesaikan kewajibannya dangan lebih cepat sehingga mengurangi tingkat keterlambatan yang akan mengganggu stabilitas perusahaan [1]. Administrasi adalah fungsi dalam organisasi niaga yang unsur-unsurnya adalah perencanaan, pengorganisasian, pemberian perintah, pengkoodinasian, dan pengawasan [2]. Izin adalah perbuatan hukum administrasi negara bersegi satu yang mengaplikasikan peraturan dalam hal konkret berdasarkan persyaratan dan prosedur sebagaimana ditetapkan oleh ketentuan peraturan perundang-undangan [4]

Perizinan pada DPMPTSP memiliki jenis dan type yang berbeda beda, berbeda type berbeda juga ketentuan pada setiap perizinannya, berikut adalah type yang terdapat pada perizinan DPMPTSP, yaitu Type A, Perizinan Dan Non Perizinan Tanpa Perlu Dilakukan Survey Lapangan Serta Tidak Memerlukan Retribusi. Type B, Perizinan Dan Non Perizinan Yang Memerlukan Survey Lapangan Tanpa Retribusi. Type C, Perizinan Dan Non Perizinan Yang Memerlukan Survey Lapangan Dengan Retribusi. Type D, Perizinan Dan Non Perizinan Yang Memerlukan Retribusi Tanpa Dilakukan Survey Lapangan. Type E, Perizinan Dan Non Perizinan Yang Memerlukan Survey Lapangan Serta Dikenakan Pajak.

Perancangan Sistem adalah suatu kegiatan membuat desain teknis berdasarkan kegiatan pada waktu proses analisis. Perancangan disini dimaksudkan suatu proses pemahaman dan peran suatu sistem informasi berbasis komputer. [7]

\section{METODE PENELITIAN}

Metode penelitian merupakan suatu tata cara atau kegiatan pelaksanaan penelitian rangka untuk mengumpulkan informasi atau data serta melakukan investigasi terhadap data yang telah didapatkan tersebut. yang didasari oleh asumsi-asumsi dasar, pandangan-pandangan filosofis dan ideologis, pertanyaan dan isu-isu yang dihadapi [3][5]. Suatu penelitian mempunyai rancangan penelitian tertentu [6][10]. Rancangan ini menggambarkan prosedur atau langkahlangkah yang harus ditempuh, waktu penelitian, sumber data dan kondisi arti untuk apa data dikumpulkan dan dengan cara bagaimana data tersebut dihimpun dan diolah untuk dianalisa dalam pembuatan laporan [11].

\section{Metode Observasi (Observasi Research)}

Pada tahapan ini penulis melakukan pengamatan langsung dari objek penelitian untuk mendapatkan data dan informasi yang akurat dan lengkap dari berbagai pihak yang terkait dan berhubungan dengan tema penelitian yang berhasil penulis rumuskan di bagian perizinan.

\section{a. $\quad$ Metode Wawancara (Interview Research)}

Penulis melakukan wawancara dengan bagian perizinan yang mengolah data perizinan, penulis mendapatkan informasi berkaitan dengan penelitian penulis.

\section{b. $\quad$ Metode Studi Pustaka (Studi Literature)}

Selain melakukan observasi penulis juga melakukan data dengan cara studi pustaka dalam metode ini penulis berusaha untuk melengkapi data-data yang diperoleh dengan membaca dan 
mempelajari dari buku-buku dan data-data yang relevan [13]. Buku dan data tersebut digunakan penulis untuk membantu penganalisaan dan perancangan yang dilakukan.

\section{Metode Analisis Data}

Pada penelitian ini, metode analisa dilakukan dengan langkah-langkah melakukan pengamatan dan analisa terhadap sistem yang berjalan saat ini, serta menentukan UML (Unified Modeling Language) yang meliputi use case diagram, activity diagram, sequence diagram [12].

\section{HASIL DAN PEMBAHASAN}

Untuk dapat menggambarkan prosedur secara keseluruhan diperlukan bebrapa tahapan analisa sebagai bentuk pengumpulan informasi guna mendapatkan model yang sesuai dengan kebutuhan dan mampu memberikan solusi dengan cepat secara efektif dan efisien, mulai dari tahapan pengumpulan informasi dan kebutuhan, analisa dokumen, merancangan hubungan antar dokumen sampai dengan merancanga model diagram database dan model rancangan sistem [8][9]. Beberapa tahapan yang dimaksud sampai dengan model ranangan yang diciptakan dapat dilihat pada gambar 1,2,3,4,5.

\section{Use Case Diagram Prosedur Berjalan}

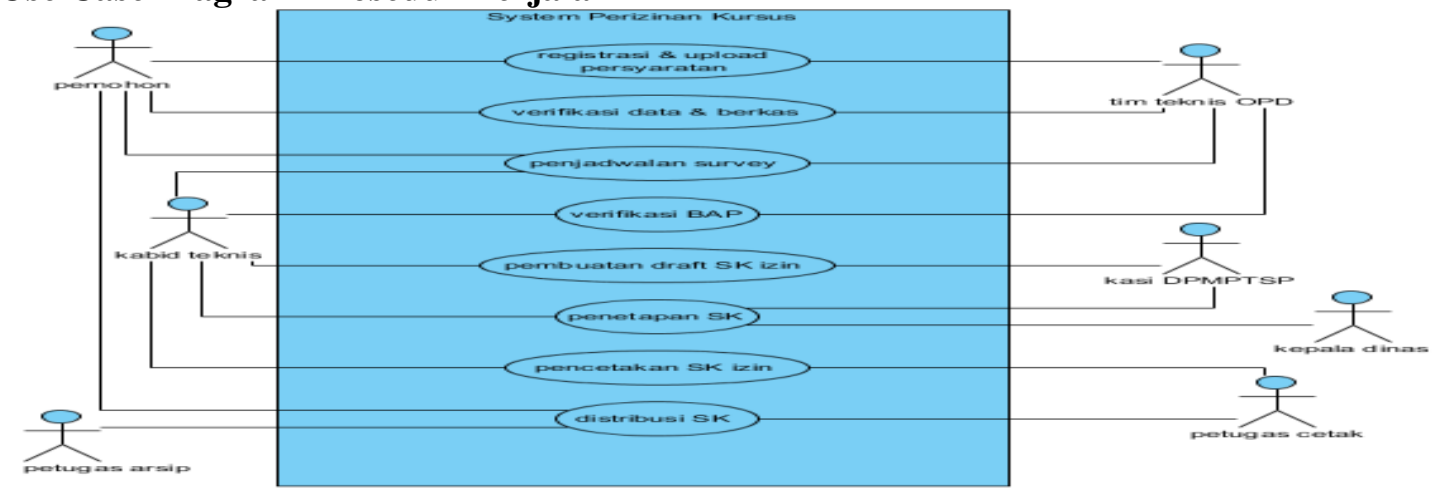

Gambar 1. Use Case Diagram

Berdasarkan gambar use case Diagram (gambar 1) yang berjalan saat ini sistem yang mencakup seluruh kegiatan pada sistem pelaporan perizinan kursus. Terdapat 7 (tujuh) Actor yang melakukan kegiatan yaitu pemohon, tim teknis OPD, kabid teknis, kasi DPMPTSP, kepala dinas, petugas cetak, dan petugas arsip yang berfungsi melakukan registrasi \& upload persyaratan, memverifikasi data \& berkas, melakukan penjadwalan survey, memverifikasi BAP, membuat draft SK izin, menetapkan SK, mencetak SK izin, dan mendistribusi SK.

Terdapat juga 8 (delapan) use case yang merupakan proses yang terjadi pada sistem berjalan yaitu melakukan registrasi \& upload persyaratan yang melibatkan pemohon dan tim teknis OPD, memverifikasi data \& berkas melibatkan pemohon dan tim teknis OPD, melakukan penjadwalan survey yang melibatkan pemohon, tim teknis OPD, dan kabid teknis, memverifikasi BAP yang melibatkan tim teknis OPD dan kabid teknis, membuat draft SK izin yang melibatkan kabid teknis dan kasi DPMPTSP, menetapkan SK yang melibatkan kabid teknis, kasi DPMPTSP, dan kepala dinas, mencetak SK izin yang melibatkan kabid teknis dan petugas cetak, mendistribusi SK yang melibatkan kabid teknis, petugas cetak dan petugas arsip. 
Activity Diagram Prosedur Berjalan

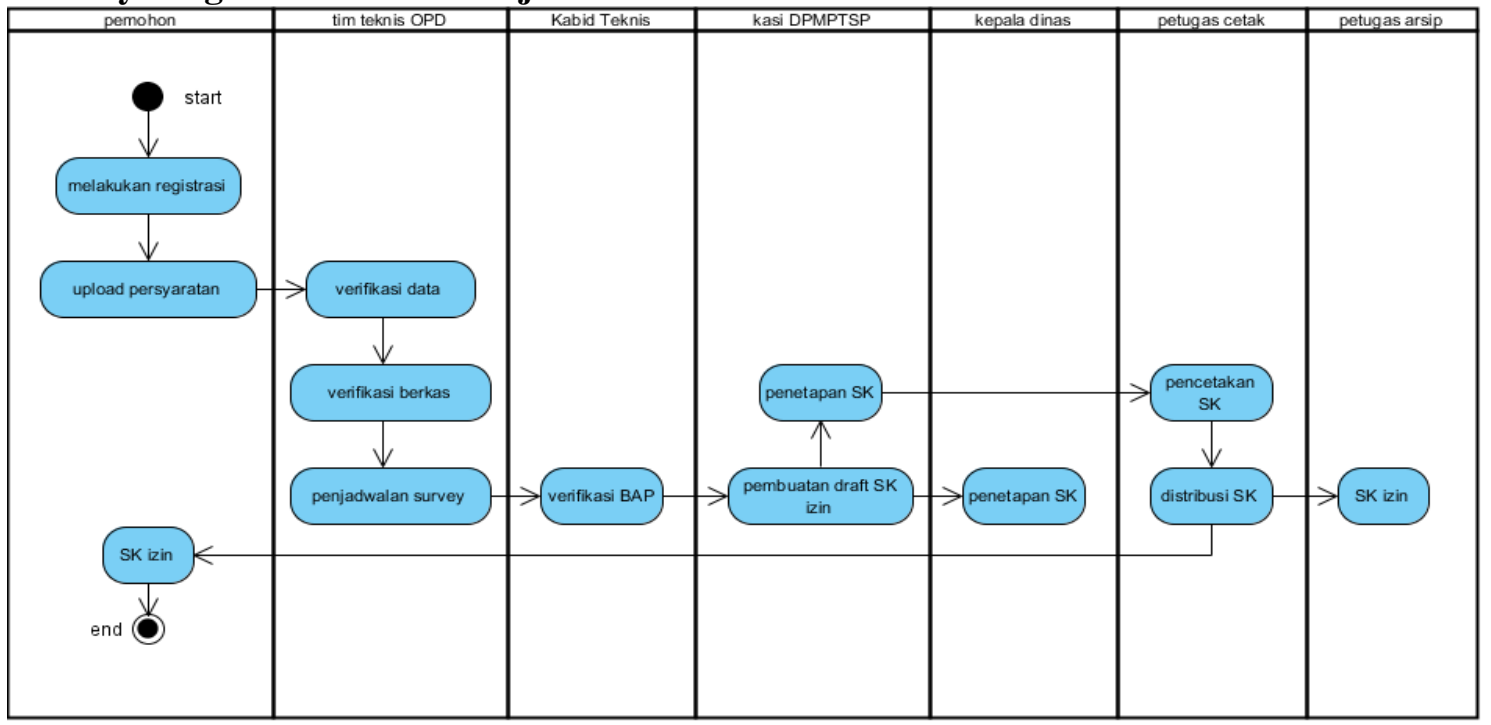

Gambar 2. Activity Diagram

Berdasarkan gambar activity diagram (gambar 2) yang berjalan saat ini sistem mencakup seluruh kegiatan pelaporan perizinan kursus. Sistem ini melibatkan 7 (tujuh) Actor yaitu, pemohon yang melakukan registrasi, upload persyaratan dan SK izin, tim teknis OPD yang menangani verfikasi data, verifikasi berkas, dan penjadwalan survey, kabid teknis yang menangani verifikasi BAP, kasi DPMPTSP yang menangani penetapan SK dan pembuatan draft SK izin, kepala dinas, yang menangani penetapan SK, petugas cetak yang menangani pencetakan SK dan distribusi SK, petugas arsip yang menangani arsip SK izin.

\section{Sequence Diagram Prosedur Berjalan}

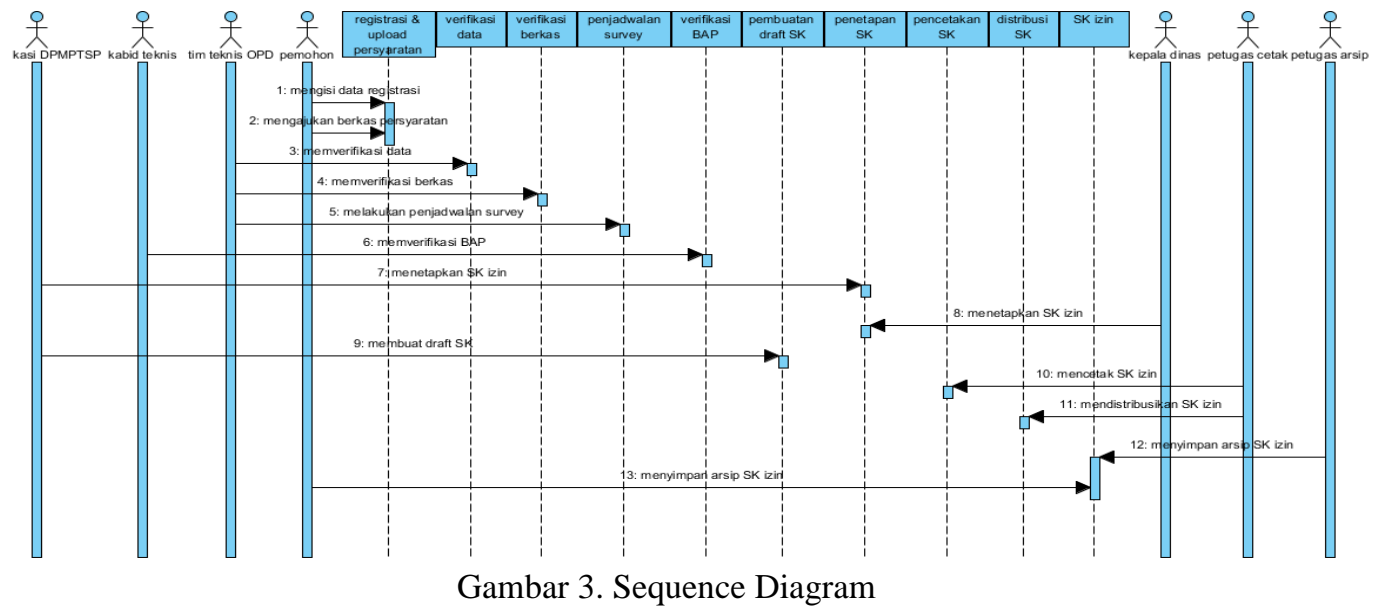

Berdasarkan gambar sequence diagram (gambar 3) yang berjalan saat ini terlihat 7 (tujuh) actor yang melakukan kegiatan diantaranya: pemohon, tim teknis OPD, kabid teknis, kasi DPMPTSP, kepala dinas, petugas cetak, dan petugas arsip yang akan menyelesaikan 13 message spesifikasi dari komunikasi antar objek yang memuat informasi-informasi tentang aktifitas yang terjadi, yaitu mengisi data registrasi, mengajukan berkas persyaratan, memverifikasi data, memverifikasi berkas, melakukan penjadwalan survey, memverifikasi BAP, menetapkan SK izin, membuat draft SK, mencetak SK izin, mendistribusikan SK izin, menyimpan arsip SK izin. 
Rancangan diatas (gambar 1, 2, 3) merupakan gambaran prosedur yang berjalan dimana pada tahapan ini melibatkan beberapa dokumen seperti form registrasi. Dimana registrasi dibuat oleh pemohon yang berfungsi sebagai data awal pemohon untuk diproses pada penjadwalan survey.

\section{Class Diagram}

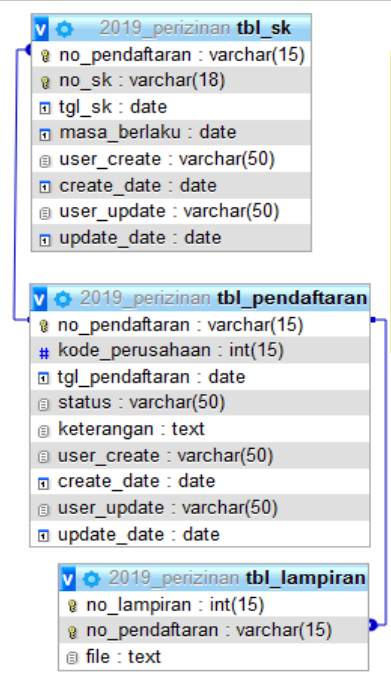

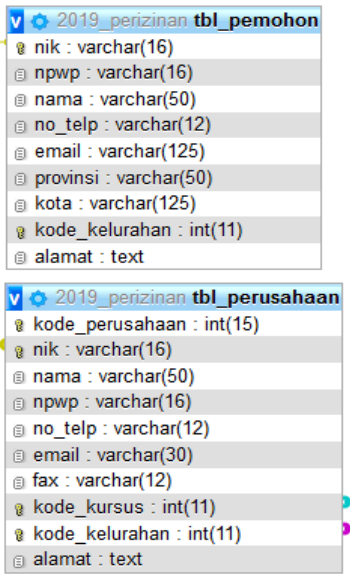

no_pendaftaran : varchar(15)

(i) file: text

\section{Gambar 4. Class Diagram}

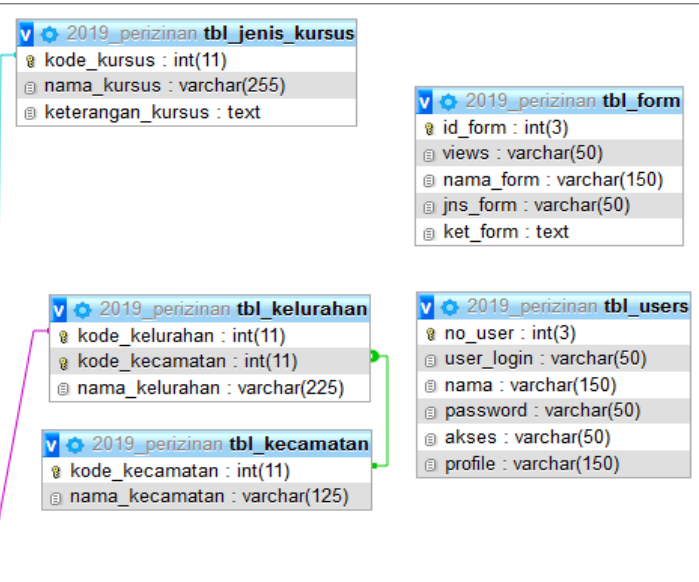

Berdasarkan gambar class diagram (gambar 4) yang berjalan saat ini sistem yang mencakup seluruh kegiatan pada sistem pelaporan perizinan kursus. Terdapat 10 (sepuluh) class yaitu user, jenis_kursus, kecamatan, kelurahan, pemohon, perusahaan dan form, merupakan tabel master dan lampiran, pendaftaran, dan sk sebagai tabel transaksi.

Berdasarkan gambar class diagram (gambar 4) diatas dapat dilihat dengan jelas bahwa tingkat hubungan tbl_sk dan tbl_pendaftaran yaitu many to one (M:1), tingkat hubungan tbl_pendaftaran dan tbl_lampiran one to many (1:M), tingkat hubungan tabel tbl_pemohon dan tbl_perusahaan one to many (1:M), tingkat hubungan tbl_perusahaan dan tbl_kelurahan many to one (M:1), tingkat hubungan tbl_perusahaan dan tbl_jenis_kursus many to one (M:1), tingkat hubungan tbl_kelurahan dan tbl_kecamatan many to one (M:1).

\section{Use Case Diagram Usulan}

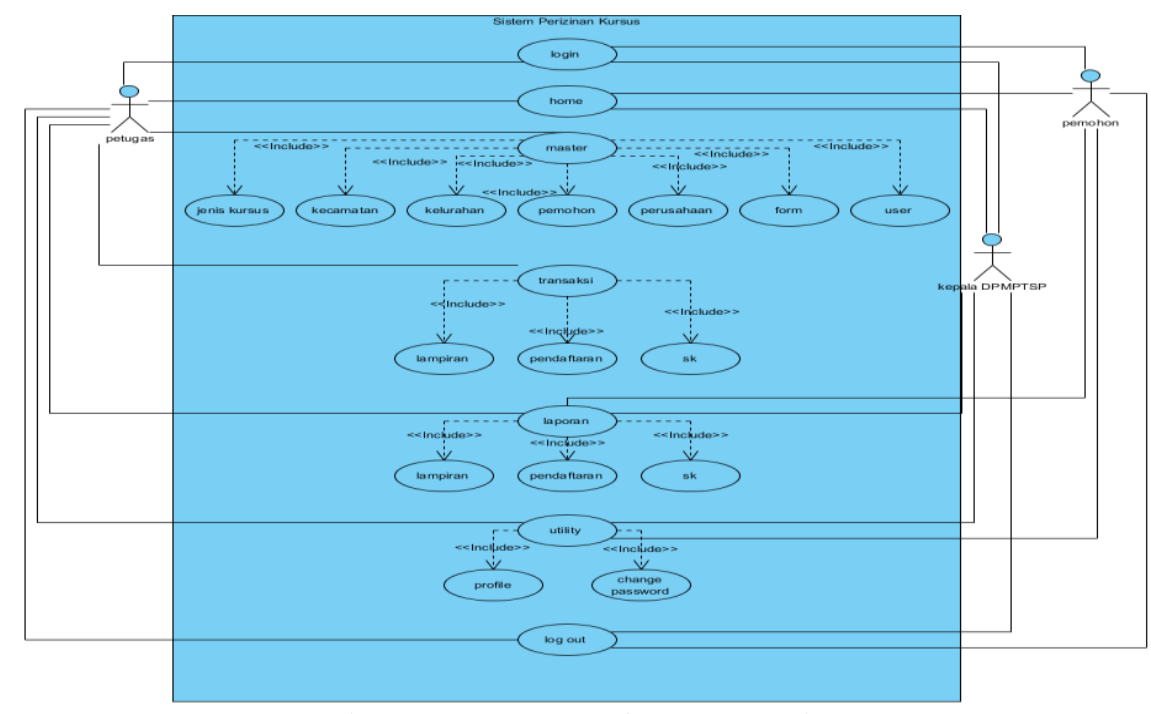

Gambar 5. Use Case Diagram Usulan 
Berdasarkan gambar use case diagram usulan (gambar 5) terlihat jelas bahwa terdapat 22 (dua puluh dua) use case yang terdiri dari 7 (tujuh) use case utama yaitu login, home, master, transaksi, laporan, utility, dan logout. Use case login terhubung dengan actor user, pemohon, petugas, dan kepala DPMPTSP. Use case master memiliki 7 (tujuh) yang terdiri dari jenis kursus, kecamatan, kelurahan, pemohon, perusahaan, user, dan form, semuanya terhubung dengan actor petugas. Use case transaksi memiliki 3 (tiga) yang terdiri dari lampiran, pendaftaran, sk, semuanya terhubung dengan actor admin. Use case laporan memiliki 3(tiga) yang terdiri dari laporan lampiran, laporan pendaftaran, dan laporan sk, semuanya terhubung dengan pemohon, petugas, dan kepala DPMPTSP. Use case utility memiliki 2 (dua) yang terdiri dari profile, dan change password semuanya terhubung dengan pemohon, petugas, dan kepala DPMPTSP.

Use diagram sebagai bentuk rancangan sistem yang akan diciptakan (gambar 5) merupakan desain model tampilan utama yang berorintasi pada kebutuhan menu pada aplikasi yang disiapkan, selain itu untuk kebutuhan penyimanan informasi data agar dapat digunakan secara histori juga digambarkan dalam bentuk class diagram (gambar 4) lengkap dengan informasi field dan type data sesuai kebutuhan penyimpanan data.

\section{IMPLEMENTASI}

\section{Rancangan Basis Data}

Untuk dapat menggamarkan bentuk basis data secara utuh, peneliti penggunakan aplikasi microsoft access sebagai bentuk gambaran dasar, dan pada akhirnya bentuk rancangan basis data ini dapat disesuaikan menggunakan apa saja sesuai kebutuhan.

\section{a. Tabel Master: User}

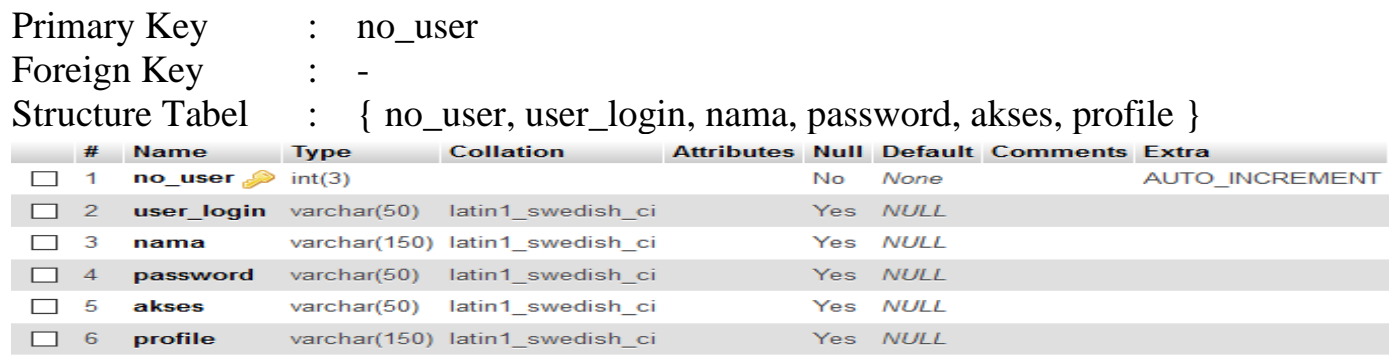

b. Tabel Master: Jenis Kursus

Tabel 1. Tabel User

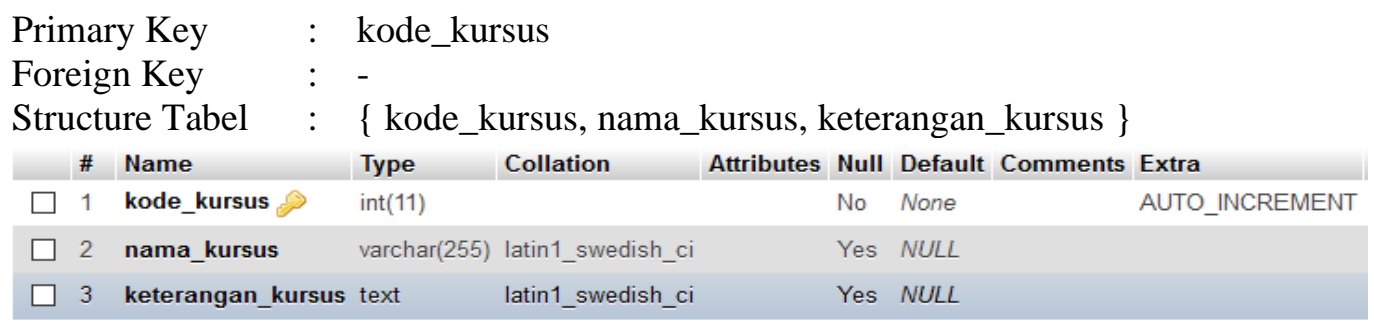

Tabel 2. Tabel Jenis Kursus

c. Tabel Master: Kecamatan

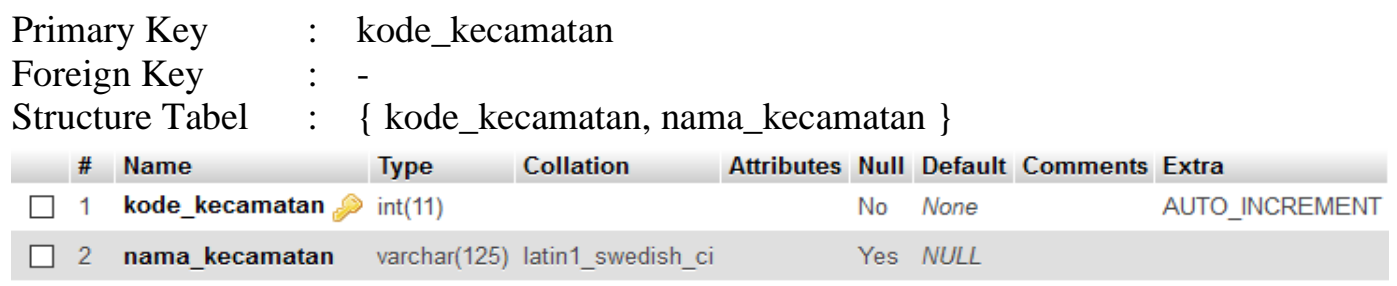

Tabel 3. Kecamatan

\section{d. Tabel Transaksi: Kelurahan}


Primary Key : kode_kelurahan

Foreign Key : kode_kecamatan

Structure Tabel : \{kode_kelurahan, kode_kecamatan, nama_kelurahan \}

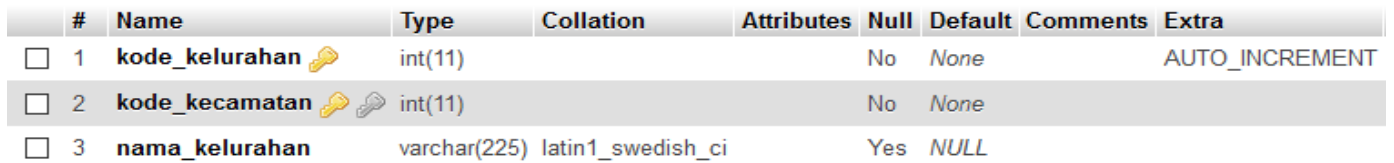

Tabel 4. Tabel Kelurahan

e. Tabel Transaksi: Lampiran

Primary Key : no_lampiran

Foreign Key : \{no_pendaftaran \}

Structure Tabel : \{no_lampiran, no_pendaftaran, file \}

\begin{tabular}{|c|c|c|c|c|c|c|c|c|}
\hline & $\#$ & Name & Type & Collation & Attributes & Null & Default Comments & Extra \\
\hline$\square$ & 1 & no_lampiran & $\operatorname{int}(15)$ & & & No & None & AUTO_INCREMENT \\
\hline$\square$ & 2 & no_pendaftaran & varchar(15) & latin1_swedish_ci & & No & None & \\
\hline$\square$ & 3 & file & text & latin1_swedish_ci & & No & None & \\
\hline
\end{tabular}

\section{f. Tabel Transaksi: Pemohon}

Primary Key : nik

Foreign Key : kode_kelurahan

Structure Tabel : \{ nik, npwp, nama, no_telp, email, provinsi, kota, kode_kelurahan, alamat \}

\begin{tabular}{|c|c|c|c|c|c|c|c|c|c|}
\hline & \# & Name & Type & Collation & Attributes & NulI & Default & Comments & Extra \\
\hline$\square$ & 1 & nik $\gg$ & varchar(16) & latin1_swedish_ci & & No & None & & \\
\hline$\square$ & 2 & npwp & varchar(16) & latin1_swedish_ci & & Yes & NULL & & \\
\hline$\square$ & 3 & nama & $\operatorname{varchar}(50)$ & latin1_swedish_ci & & Yes & NULL & & \\
\hline$\square$ & 4 & no_telp & varchar(12) & latin1_swedish_ci & & Yes & NULL & & \\
\hline$\square$ & 5 & email & varchar(125) & latin1_swedish_ci & & Yes & NULL & & \\
\hline$\square$ & 6 & provinsi & $\operatorname{varchar}(50)$ & latin1_swedish_ci & & Yes & NULL & & \\
\hline$\square$ & 7 & kota & varchar(125) & latin1_swedish_ci & & Yes & NULL & & \\
\hline$\square$ & 8 & kode_kelurahan & int(11) & & & No & None & & \\
\hline$\square$ & 9 & alamat & text & latin1_swedish_ci & & Yes & NULL & & \\
\hline
\end{tabular}

Tabel 6. Tabel Pemohon

\section{g. Tabel Transaksi: Pendaftaran}

Primary Key : no_pendaftaran

Foreign Key : kode_perusahaan

Structure Tabel : \{ no_pendaftaran, kode_perusahaan, tgl_pendaftaran, status, keterangan, user_create, create_date, user_update, update_date \}

\begin{tabular}{|c|c|c|c|c|c|c|c|c|c|}
\hline & \# & Name & Type & Collation & Attributes & Null & Default & Comments & Extra \\
\hline$\square$ & 1 & no_pendaftaran & varchar(15) & latin1_swedish_ci & & No & None & & \\
\hline$\square$ & 2 & kode_perusahaan & int(15) & & & Yes & NULL & & \\
\hline$\square$ & 3 & tgl_pendaftaran & date & & & Yes & NULL & & \\
\hline$\square$ & 4 & status & varchar(50) & latin1_swedish_ci & & No & None & & \\
\hline$\square$ & 5 & keterangan & text & latin1_swedish_ci & & No & None & & \\
\hline$\square$ & 6 & user_create & varchar(50) & latin1_swedish_ci & & No & None & & \\
\hline$\square$ & 7 & create_date & date & & & No & None & & \\
\hline$\square$ & 8 & user_update & varchar(50) & latin1_swedish_ci & & No & None & & \\
\hline$\square$ & 9 & update_date & date & & & No & None & & \\
\hline
\end{tabular}

Tabel 7. Tabel Pendaftaran

h. Tabel Transaksi: Perusahaan

Primary Key : kode_perusahaan 
Foreign Key $\quad:$ nik, kode_kursus, kode_kelurahan

Structure Tabel : \{ kode_perusahaan, nik, nama, npwp, no_telp, email, fax, kode_kursus, kode_kelurahan, alamat \}

\begin{tabular}{|c|c|c|c|c|c|c|c|c|}
\hline & $\#$ & Name & Type & Collation & Attributes & Null & Default Comments & Extra \\
\hline$\square$ & 1 & kode_perusahaan & $\operatorname{int}(15)$ & & & No & None & AUTO_INCREMENT \\
\hline$\square$ & 2 & nik $\odot$ & $\operatorname{varchar}(16)$ & latin1_swedish_ci & & No & None & \\
\hline$\square$ & 3 & nama & $\operatorname{varchar}(50)$ & latin1_swedish_ci & & Yes & NULL & \\
\hline$\square$ & 4 & npwp & $\operatorname{varchar}(16)$ & latin1_swedish_ci & & Yes & NULL & \\
\hline$\square$ & 5 & no_telp & $\operatorname{varchar}(12)$ & latin1_swedish_ci & & Yes & NULL & \\
\hline$\square$ & 6 & email & $\operatorname{varchar}(30)$ & latin1_swedish_ci & & Yes & NULL & \\
\hline$\square$ & 7 & fax & $\operatorname{varchar}(12)$ & latin1_swedish_ci & & Yes & NULL & \\
\hline$\square$ & 8 & kode_kursus $\gg$ & $\operatorname{int}(11)$ & & & No & None & \\
\hline$\square$ & 9 & kode_kelurahan & $\operatorname{int}(11)$ & & & No & None & \\
\hline$\square$ & 10 & alamat & text & latin1_swedish_ci & & Yes & NULL & \\
\hline
\end{tabular}

Tabel 8. Tabel Perusahaan

i. Tabel Transaksi: SK

Primary Key : no_sk

Foreign Key : no_pendaftaran

Structure Tabel : \{ no_pendaftaran, no_sk, tgl_sk, masa_berlaku, user_create, create_date, user_update, update_date \}

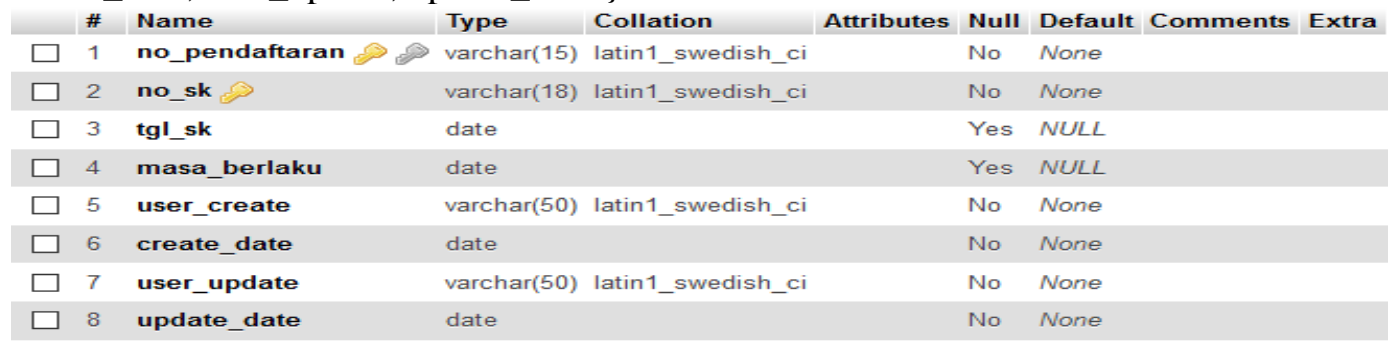

Tabel 9. Tabel SK

j. Tabel Transaksi: Form

Primary Key : id_form

Foreign Key :

Structure Tabel : $\quad\{$ id_form, views, nama_form, jns_form, ket_form $\}$

\begin{tabular}{|llllll} 
\# & Name & Type & Collation & Attributes & Null Default Comments Extra \\
$\square$ & 1 & id_form & $\operatorname{int}(3)$ & No & None \\
$\square$ & 2 & views & $\operatorname{varchar}(50)$ & latin1_swedish_ci & Yes NULL \\
$\square$ & 3 & nama_form & $\operatorname{varchar}(150)$ & latin1_swedish_ci & Yes NULL \\
$\square$ & 4 & jns_form & $\operatorname{varchar}(50)$ & latin1_swedish_ci & Yes NULL \\
$\square$ & 5 & ket_form & text & latin1_swedish_ci & Yes NULL \\
& & & Tabel 10. Tabel Form
\end{tabular}




\section{Grafik Rekapitulasi Pengajuan Berkas}

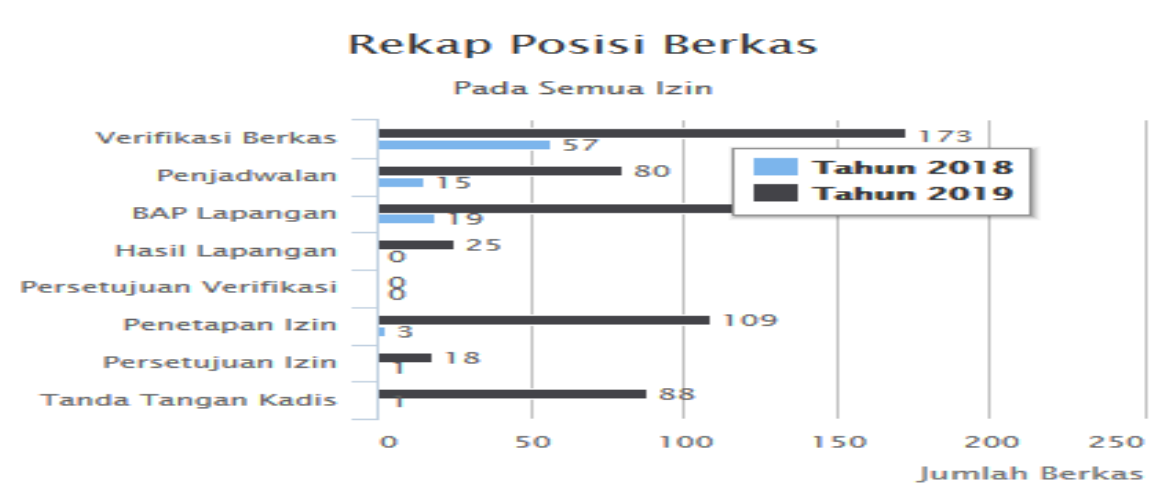

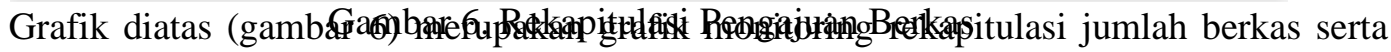
posisi penanganan pada tahun berjalan. Grafik diatas bisa diambil berdasarkan Datewarehouse, sebagaimana di definisikan "Doing Data Warehouse $(D W)$ to your business or system is not only think about the trend only, but how to understand the DW knowledge itself and how to implement it" [14]. Dan bagaimana cara mengukurnya "Measures are a standard unit used to express the size, amount, or degree of something, qualities are often difficult to be measured as it needs to have some certain parameter or elements, and those parameters must be quantifiable and verifiable" [15]

\section{Diagram HIPO}

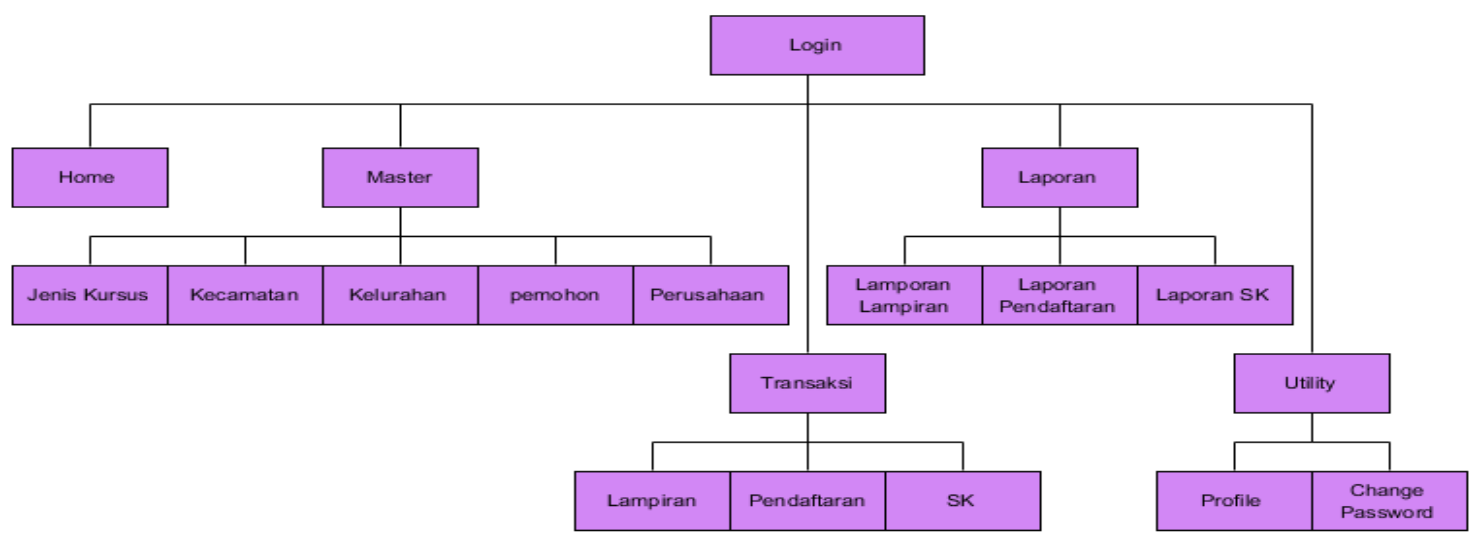

Gambar 7. Diagram HIPO

Untuk menggambarkan stuktur menu dari sistem yang dirancang dapat digambarkan dengan diagram HIPO (Hierarchy Input Process Output). Untuk menyediakan suatu struktur guna memahami fungsi-fungsi dari program. Terlihat dari diagram HIPO diatas (gambar 7) terdapat 1 (satu) fungsi utama yaitu login (digram 0) dan 5 (lima) fungsi dibawahnya, yaitu fungsi menu home( diagram 1) menu master (diagram 2), menu transaksi (diagram 3) dan menu laporan (diagram 4) dan menu utility (diagram 5). Didalam fungsi menu home (diagram 1) menu master (diagram 2) terdapat 5 (lima) fungsi sub menu yaitu fungsi menu pengelolaan jenis_kursus (diagram 2.1), pengelolaan kecamatan (diagram 2.2), pengelolaan kelurahan (diagram 2.3), pengelolaan menu pemohon (diagram 2.4), dan pengelolaan menu perusahaan (diagram 2.5). Didalam fungsi menu transaksi (diagram 3) terdapat 3 (tiga) fungsi fungsi sub menu yaitu fungsi menu pengelolaan data lampiran (diagram 3.1), pengelolaan data pendaftaran (diagram 3.2), dan pengelolaan data sk (diagram 3.3). Didalam fungsi laporan (diagram 4) terdapat 3 (tiga) fungsi sub menu yaitu fungsi menu pengelolaan data laporan lampiran (diagram 4.1), pengelolaan data laporan pendaftaran (diagram 4.2), dan pengelolaan data laporan sk 
(diagram 4.3). Didalam fungsi utility (diagram 5) terdapat 2 (dua) fungsi sub menu yaitu fungsi menu pengelolaan data profile (diagram 5.1), dan pengelolaan data change password (diagram 5.2).

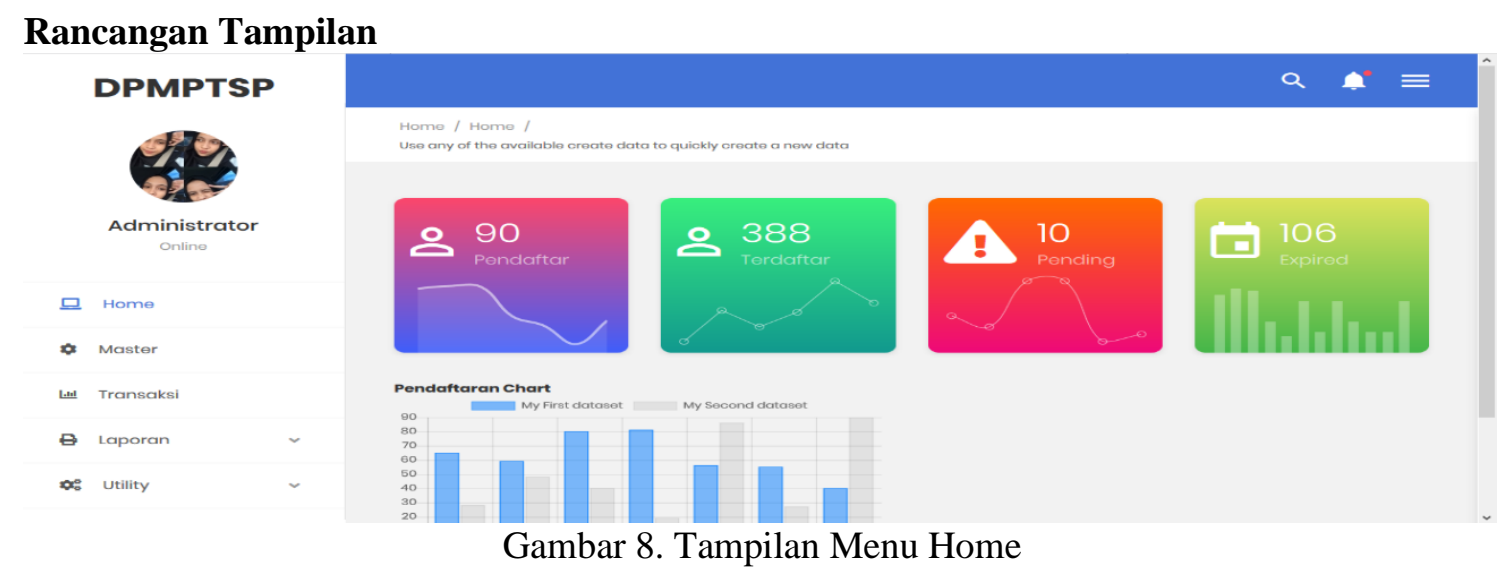

Terlihat pada tampilan layar diatas (gambar 8) merupakan tampilan layar utama yang terdiri dari menu home, menu master, menu transaksi menu laporan, menu utility dan logout.

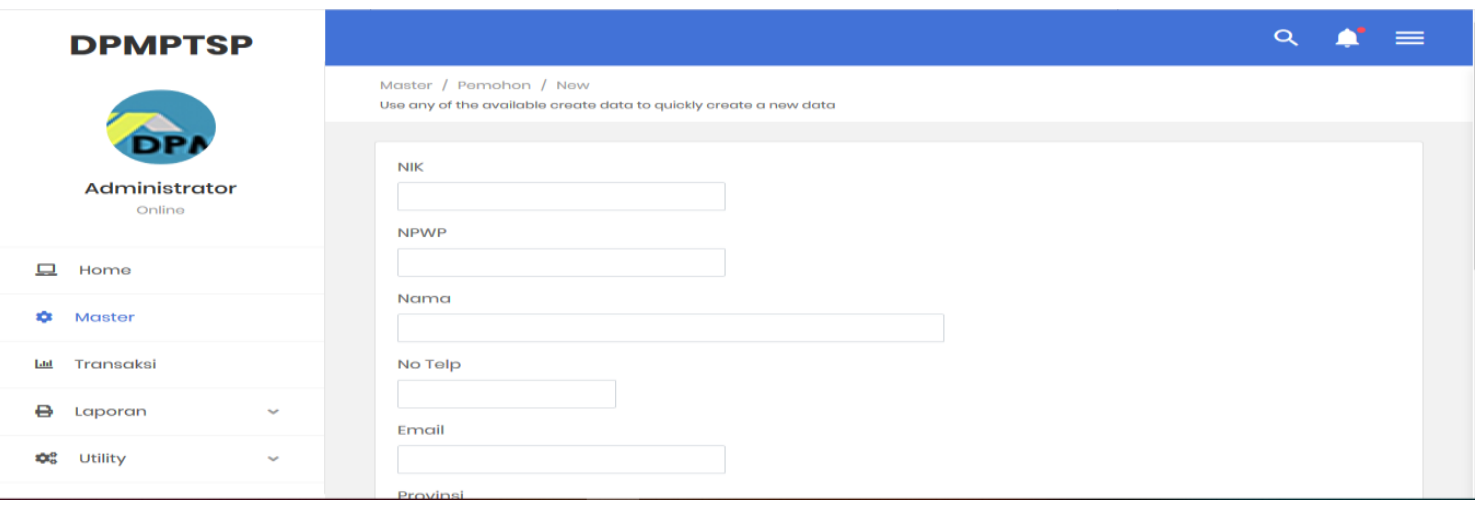

Gambar 9. Tampilan Input Data Pemohon

Terlihat pada tampilan layar diatas (gambar 9) merupakan tampilan input data pemohon yang terdiri dari nik, NPWP, nama, no telp, email, provinsi, kota, kelurahan, alamat.

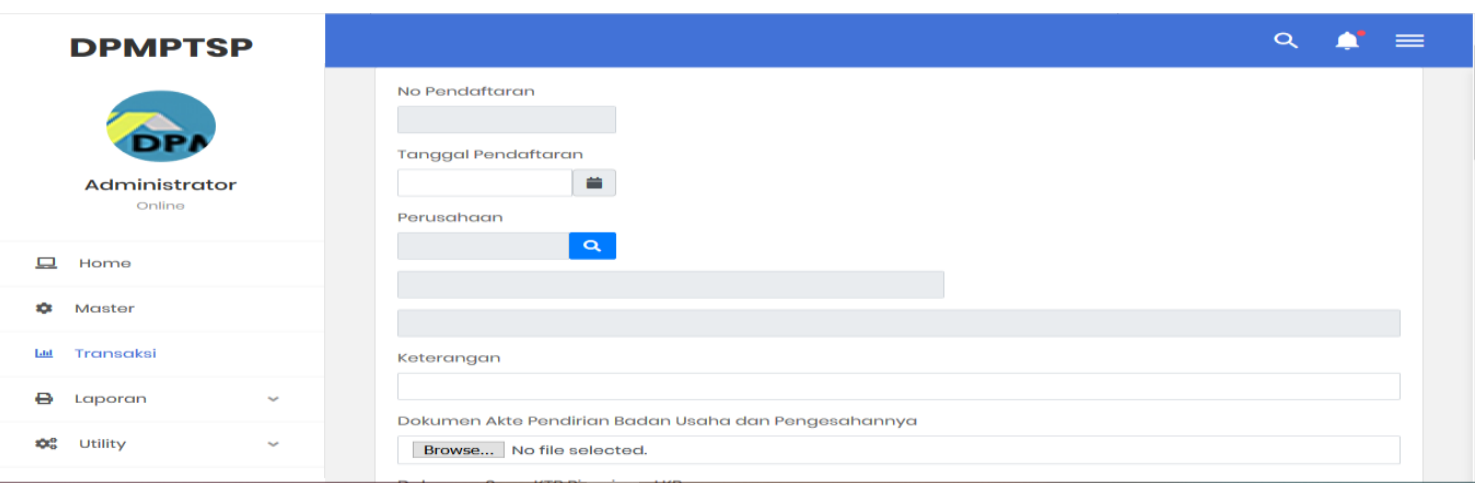

Gambar 10. Tampilan Layar Pendaftaran

Terlihat pada tampilan layar diatas (gambar 10) merupakan tampilan layar pendaftaran yang terdiri dari no pendaftaran, tanggal pendaftaran, perusahaan, keterangan, dan beberapa fasilitas upload berkas untuk lampiran yang diperlukan. 


\section{Query Penciptaan Informasi}

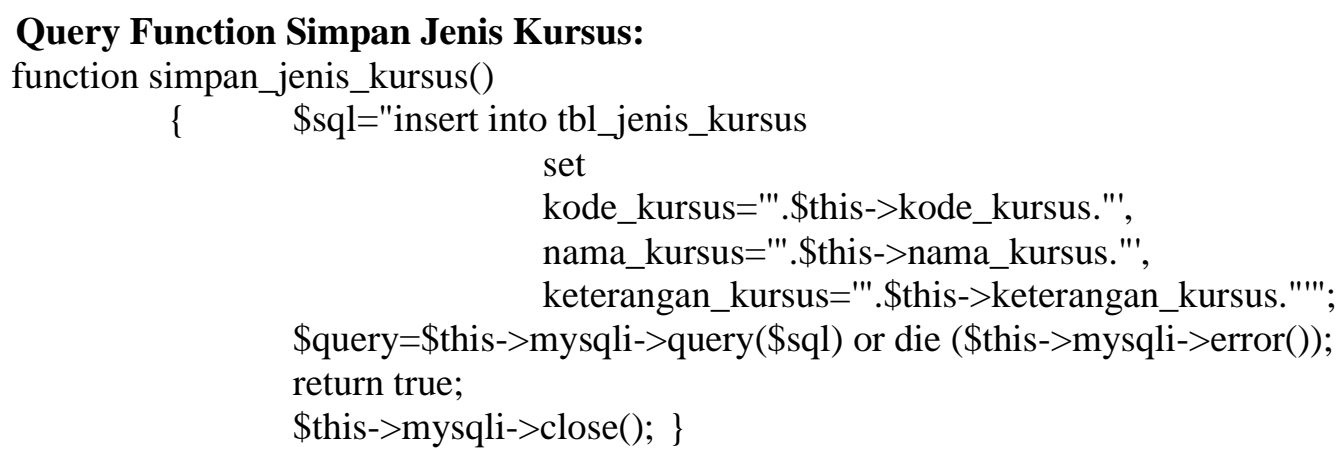

Query Function List Jenis Kursus:

function list_jenis_kursus()

\{ $\quad$ \$sql="select * from tbl_jenis_kursus";

\$this->sql=\$sql;

$\$ \mathrm{i}=0$;

\$query=\$this->mysqli->query( $\$$ sql) or die (\$this->mysqli->error());

while (\$result=\$query->fetch_assoc())

\{ $\quad$ \$this->kode_kursus[\$i]=\$result['kode_kursus'];

\$this->nama_kursus[\$i]=\$result['nama_kursus'];

\$this->keterangan_kursus[\$i]=\$result['keterangan_kursus'];

$\$ i++; \quad\}$

return true;

\$this->mysqli->close (); \}

\section{Query Function Edit Jenis Kursus:}

function edit_jenis_kursus()

$\{\quad$ \$sql="update tbl_jenis_kursus

set

kode_kursus='".\$this->kode_kursus."',

nama_kursus='".\$this->nama_kursus."',

keterangan_kursus='".\$this->keterangan_kursus."'

where kode_kursus='".\$this->kode_kursus."'";

\$query=\$this->mysqli->query (\$sql) or die (\$this->mysqli->error());

return true;

\$this->mysqli->close(); \}

\section{KESIMPULAN}

Sistem administrasi perizinan kursus tempat objek penelitian saat ini sebenarnya sudah memliki sistem perizinan online melalui website tersendiri untuk perizinan kursus, namun pada prakteknya kedua aplikasi sistem ini jarang dipakai oleh masyarakat yang ingin mengurus izin karena jarang berbagai alasan, diantaranya kendala persyaratan administratif yang dirasa menyulitkan, kendala akses yang terkadang bermasalah, lamanya waktu respon disbanding datang langsung dan lain sebagainya berbagai alas an, hal ini bisa dilihat dari banyaknya masyarakat yang datang langsung ke untuk mengurus perizinan tanpa menggunakan sistem yang ada saat ini. Sistem yang dirancang sebagai solusi untuk permasalahan yang ada menggunakan uml sebagai desain concept, MySql sebagai media pengelolaan database dan php sebagai bahasa pemrograman serta ditambah beberapa analisa kebutuhan yang didapat pada 
tahapan analisa diharapkan mampu menjadi sistem pendamping dari yang ada saat ini khusus menangani masyarakat yagn dating langsung.

\section{DAFTAR PUSTAKA}

[1] Junaidi, J., Roji, A., \& Munawar, K. (2015). Konsep Otomatisasi Sistem Pembayaran SPP Online Untuk Mengurangi Tingkat Keterlambatan. Proceedings Konferensi Nasional Sistem dan Informatika (KNS\&I)..

[2] Mahmud, Hilal. (2015). Administrasi pendidikan (Menuju Sekolah Efektif). Makasar: Penerbit Aksara Timur.

[3] Junaidi, T. K. Y. N. D. (2013). Sistem Pakar Monitoring Inventory Control Untuk Menghitung Harga Jual Efektif Dalam Meningkatkan Keuntungan. Yogyakarta: Universitas Ahmad Dahlan.

[4] Puang, Victorianus M.H. Randa. (2015). Hukum Pendirian Usaha Dan Perizinan. Yogyakarta: Deepublish.

[5] Junaidi, J., Effendy, M. Y., \& Hartono, H. (2015). REKAYASA MODEL APLIKASI SISTEM PRODUCT KNOWLADGE UNTUK MENDUKUNG PENGAMBILAN KEPUTUSAN DALAM MENENTUKAN KINERJA KARYAWAN. CERITA Journal, 1(1), 46-55.

[6] Henderi, H., Junaidi, J., \& Kusuma, T. A. H. (2012). Dashboard Monitoring System Penjualan Dan Reward Mobile Kios PT. Telekomunikasi Seluler. Semantik, 2(1)..

[7] Junaidi, J., Arifin, R., \& Septiani, A. (2015). Rancang Bangun Aplikasi Sistem Inventory Berbasis Desktop Menggunakan JSE. Proceedings Konferensi Nasional Sistem dan Informatika (KNS\&I)..

[8] Hidayat, Wahyu, Riri Mahmuriyah, dan Sri Ndayani Ratna Safitri. 2016. Media Visual Berbentuk Katalog Produk Sebagai Media Promosi. ISSN: 2461-1409. Jurnal SENSI Vol.2 No. 2-Agustus 2016. Tangerang : Perguruan Tinggi Raharja.

[9] Junaidi, J., Setianingsih, R., \& Khotimah, K. (2015). Rancang Bangun Sistem Penerimaan Dan Pengeluaran Barang Menggunakan Java Aplikasi. Proceedings Konferensi Nasional Sistem dan Informatika (KNS\&I)..

[10] Asbar, Yuli, dan Mochamad Ari Saptari. 2017. "Analisa Dalam Mengukur Kualitas Pelayanan Terhadap Kepuasan Konsumen Menggunakan Metode PIECES”. Jurnal Visioner \& Strategis Vol. 6 Nomor 2, September 2017: 39-47 Universitas Malikussaleh.

[11] Junaidi, J., Santoso, S., \& Sunarya, L. (2008). Rekayasa Teknik Pemrograman Pencegahan Dan Perlindungan Dari Virus Lokal Menggunakan API Visual Basic. CCIT Journal, 1(2), 134-153..

[12] Martono, A., \& Junaidi, D. Y. IMULATION GAME BASED ON JARIMAGIC METHOD TO CALCULATE MORE QUICKLY FOR ELEMENTARY STUDENTS.

[13] Junaidi, J., Cholisoh, N., \& Hasanah, N. (2018). Rancang Bangun Sistem Manajemen Aset IT Untuk Pencatatan History Maintenance Sebagai Pendukung Keputusan. SENSI Journal, 4(2), 220-231.. 
[14] M. Subekti, Warnars Junaidi, H.L.H.S., Y. Heryadi, "The 3 steps of best data warehouse model design with leaning implementation for sales transaction in franchise restaurant", Cybernetics and Computational Intelligence (CyberneticsCom) 2017 IEEE International Conference on, 20-22 Nov 2017.

[15] J. Junaidi, A. Julianto, N. Anwar, S. Safrizal, H.L.H.S. Warnars, K. Hashimoto, "Perfecting a Video Game with Game Metrics", Telkomnika, vol. 16, no. 3, pp. 13241331, June 2018 